\title{
The Importance of Vitamin D Deficiency as a Potential Marker Among Chronic Hepatitis B Patients
}

\section{Kronik Hepatit B Hastalarında Potansiyel Belirteç Olarak D Vitamini Eksikliğinin Önemi}

\author{
๑ Freshteh Osmani, ๑ Masood Ziaee
}

Birjand University of Medical Sciences, Department of Infectious Disease Research Center, Birjand, Iran

\begin{abstract}
Objectives: We aimed to identify the potential role of vitamin $D_{3}$ among patients with chronic hepatitis B (CHB) in Birjand, Iran.

Materials and Methods: In this case-control study, 292 patients were selected with $\mathrm{CHB}$ and 304 healthy subjects as control groups in the outpatient clinic of the infectious diseases department between January 2018 and December 2019. We quantified the levels of total vitamin $D_{3}$ in serum samples of them. Logistic statistical analysis was applied at the significance level of $5 \%$.

Results: The mean age and serum vitamin $\mathrm{D}_{3}$ level of the study and control groups were; $39.9 \pm 12.3$ years, $43.0 \pm 9.3$ years and $17.76 \pm 5.53 \mathrm{ng} / \mathrm{mL}, 22.07 \pm 2.41 \mathrm{ng} / \mathrm{mL}$, respectively. So, a significant difference between means of vitamin $D_{3}$ serum in the two groups was observed $(p>0.05)$. The prevalence of vitamin $\mathrm{D}_{3}$ deficiency was higher among patients with hepatitis $\mathrm{B}$ virus $(63.0 \%)$ than the healthy group $(32.9 \%)$. Frequency distribution of serum vitamin $D_{3}$ levels showed a significant difference between the two groups $(p=0.001)$. The risk of vitamin $D_{3}$ deficiency was significantly more than the healthy group lodds ratio: $3.17, p<0.001$ ).

Conclusions According to the results; a high risk of vitamin $D_{3}$ deficiency related to $\mathrm{CHB}$ was found in this city. Future studies are warranted to consider the impact of vitamin D supplementation in $\mathrm{CHB}$.
\end{abstract}

Keywords: Vitamin $\mathrm{D}_{3}$ level, liver disease, chronic HBV infection
ÖZ

Amaç: Iran, Birjand'daki kronik hepatit B (KHB) hastalarında vitamin $\mathrm{D}_{3}$ 'ün potansiyel rolünü belirlemeyi amaçladık.

Gereç ve Yöntemler: Bu olgu-kontrol çalışması için, Ocak 2018 ile Aralık 2019 tarihleri arasında enfeksiyon hastalıkları bölümü polikliniğinden KHB'li 292 hasta ve kontrol grubu olarak 304 sağlıklı denek seçildi. Bunların serum örneklerindeki total vitamin $\mathrm{D}_{3}$ düzeylerini belirledik. Lojistik istatistiksel analiz $\% 5$ anlamlılık düzeyinde uygulanmıştır.

Bulgular: Çalışma ve kontrol gruplarının yaş ortalamaları ve serum vitamin $D_{3}$ düzeyleri sırasıyla; $39,9 \pm 12,3$ yıl, $43,0 \pm 9,3$ yıl ve $17,76 \pm 5,53 \mathrm{ng} / \mathrm{mL}, 22,07 \pm 2,41 \mathrm{ng} / \mathrm{mL}$ idi. Iki grup arasında serum vitamin $\mathrm{D}_{3}$ ortalamaları arasında anlamlı bir fark gözlendi $(p>0,05)$. Vitamin $\mathrm{D}_{3}$ eksikliği prevalansı KHB'li hastalarda $(\% 63,0)$ kontrol grubuna göre $(\% 32,9)$ yüksekti. Vitamin $D_{3}$ seviyelerinin frekans dağılımı iki grup arasında anlamlı farklılık gösterdi $(p=0,001)$. Vitamin $D_{3}$ eksikliği riski control grubuna göre anlamlı derecede fazlaydı (olasilık oranı: 3,17, $\mathrm{p}<0,001$ ).

Sonuç: Sonuçlara göre; bu şehirde KHB'ye bağlı yüksek vitamin $\mathrm{D}_{3}$ eksikliği riski bulundu. Her ne kadar gelecekteki çalışmaların KHB'de D vitamini takviyesinin etkisini dikkate alması garanti edilse de. Gelecekteki çalışmaların KHB'de D vitamini takviyesinin etkisi üzerine olması beklenmektedir.

Anahtar Kelimeler: Vitamin $\mathrm{D}_{3}$ düzeyi, karaciğer hastalığı, kronik HBV enfeksiyonu

Osmani F, Ziaee M. The Importance of Vitamin D Deficiency as a Potential Marker Among Chronic Hepatitis B Patients. Viral Hepat J. 2021;27:74-79. 


\section{Introduction}

The liver is the main place for vitamin $D_{3}$ synthesis, where 25-hydroxylation occurs (1). Vitamin $D_{3}$ plays an appearing role in metabolic liver diseases. There is evidence about the interrelationship between vitamin $D_{3}$ and different chronic liver diseases owing to its immunomodulatory role $(2,3)$. About 240 million individuals are infected with hepatitis B virus (HBV) chronically all over the world (4).

It has been shown that vitamin $D_{3}$ has very important biologic effects $(5,6)$. Vitamin $D_{3}$ levels can affect the immune system and host response to HBV infection.

But, the association between vitamin $D_{3}$ metabolism and chronic hepatitis $B(\mathrm{CHB})$ is less well characterized yet (7).

Different studies suggested low levels of vitamin $D_{3}$ are associated with high levels of HBV replication in CHB patients recently. Although, a study found a positive relationship between hepatitis B surface antigen ( $\mathrm{HBs} A g$ ) seroclearance and vitamin $D_{3}$ levels (8).

Also, another one showed a significant relationship between higher levels of HBV replication and low levels of vitamin $D_{3}$ in $\mathrm{CHB}$ infection (9). In addition, the role of vitamin $\mathrm{D}_{3}$ may also affect disease progression in patients with HBV infection.

According to the mentioned contents, it was assumed that vitamin $D_{3}$ level may be one of the responsible agents for the very low serum levels of CHB patients. So, the purpose of this study was to specify the risk, associated factors, and symptoms related to vitamin $\mathrm{D}_{3}$ deficiency among $\mathrm{CHB}$ patients compared to healthy individuals in Birjand.

\section{Materials and Methods}

This case-control study was carried out in Khorasan Jonoobi province of Iran in 2019 in the outpatient clinic of the infectious diseases department.

\section{Sampling}

In this study, 292 patients with CHB (HBsAg positive, anti-HBs negative), were randomly selected according to the calculated sample size by the following formula with a power of $90 \%$. In addition, 304 natural immunized persons (HBsAg negative, antiHBs has normal liver enzymes who have not received antiviral treatment were included. the healthy group was selected from collected samples of the master plan of the province (26).

$$
n=\left[\frac{\frac{z_{1-\alpha}}{2}+z_{1-\beta}}{0.51 n\left(\frac{1+r}{1-r}\right)}\right\rfloor+3
$$

\section{Vitamin $D_{3}$ Level Classification}

Total vitamin $\mathrm{D}_{3}$ levels were measured in the serum samples. Based on the World Health Organization, a level of $30 \mathrm{ng} / \mathrm{mL}$ or above is considered as vitamin $D_{3}$ sufficiency (10). Then, vitamin $D_{3}$ status was classified as normal $(\geq 30 \mathrm{ng} / \mathrm{mL})$, insufficient (20-29.9 $\mathrm{ng} / \mathrm{mL})$, and deficient $(<20 \mathrm{ng} / \mathrm{mL})$.

\section{Laboratory Tests}

For laboratory tests, 10 ccs of venous blood were taken from patients and healthy controls. The serum levels of vitamin $D_{3}$ were measured using a COBAS e411 analyzer, manufactured by Mannheim Roch diagnostic Gmbh in Germany, with the Elecsys kit (REF0589413). Other tests were performed on patients and healthy controls according to laboratory routines. Levels of alanine transaminase (ALT), aspartate transaminase (AST), (glycated hemoglobin) hemoglobin $\mathrm{A} 1 \mathrm{C}(\mathrm{HbA} 1 \mathrm{C})$ and bilirubin levels of liver enzymes were measured by the ARCHITECT I system biochemical auto-analyzer. Levels of total cholesterol, low-density lipoprotein (LDL), high-density lipoprotein (HDL), fasting blood sugar (FBS), and body mass index (BMI) were also measured.

The inclusion criteria for $\mathrm{CHB}$ patients were: patients who were admitted to the infectious diseases outpatient clinic with the diagnosis of $\mathrm{CHB}$ with the approval of the infectious specialist according to clinical and serological signs, willingness to participate in the study, didn't receive supplementation or injection of calcium and vitamin $D_{3}$ in the last six months and also with age $\geq 18$ years. In addition, 304 healthy subjects without a history of hepatitis B disease were selected as healthy control group 26.

Patients' and healthy controls exclusion criteria include severe renal disease, history of cardiovascular disease, co-infection with cancer, pregnancy, diabetic disease, thyroid disorders, other viral hepatitis (hepatitis C virus, hepatitis D virus, human immunodeficiency virus), and other causes of liver disease such as alcohol consumption.

Variables of interest were: age, sex, BMI, and clinical symptoms such as FBS, glycated $\mathrm{HbA} 1 \mathrm{C}$, blood pressure, and HBsAg.

\section{Ethics Approval}

This study was approved by the Birjand University of Medical Sciences (BUMS) Ethics Board Committee (approval number: IR.BUMS.REC.1398.324).

\section{Statistical Analysis}

Descriptive statistics were used to describe the data, chisquare test was applied to determine the difference of symptoms related to vitamin $D_{3}$ deficiency between the study groups. Also, logistic regression was done to specify the relationship between considered variables and vitamin $D_{3}$ deficiency in two groups. All analysis was done by SPSS version 22.0. The significance in all of these tests was two-tailed with a $5 \%$ significance level.

\section{Results}

Out of the all subjects who participated in the study, $48.6 \%$ were male in the case group; with a mean age $29 \pm 5.3$; and $52.2 \%$ female with mean age (31.5 \pm 7.8 ); also, of the 304 healthy subjects, $22.1 \%$ male; mean age $23.1 \pm 7.7$, and $77.8 \%$ female with mean age 29.1 \pm 11.7 . So; the distribution of gender was similar in the patients' group (Table 1). Healthy controls were younger than patients but no significant difference between them was observed ( $p>0.05$ ). So that, the mean age of the $\mathrm{CHB}$ and control groups were, $32.9 \pm 12.3$ years and $28.18 \pm 11.21$ years, respectively. There was no significant difference in $\mathrm{HbA} 1 \mathrm{C}$ level between genders, $5.71 \%$ vs $5.43 \%(p=0.343)$ (Table 1$)$. 
The mean of vitamin $\mathrm{D}_{3}$ serum levels in the $\mathrm{CHB}$ and control groups were; $17.76 \pm 5.53 \mathrm{ng} / \mathrm{mL}, 22.07 \pm 2.41 \mathrm{ng} / \mathrm{mL}$, respectively with significant differences $(p=0.031)$. When categorized as deficient, insufficient, and sufficient. Then among the healthy subjects, vitamin $\mathrm{D}_{3}$ levels were classified as $32.9 \%, 25.96 \%$, and $41.15 \%$, respectively.

Of 292 patients, 184 (63.1\%), 56 (19.2\%), and 52 (17.8\%) had vitamin $D_{3}$ deficiency, insufficiency, and sufficient vitamin $D_{3}$ serum levels, respectively. The prevalence of vitamin $D_{3}$ deficiency was high among $\mathrm{CHB}$ patients (63.1\%) as well as in healthy individuals (32.9\%). Vitamin $D_{3}$ levels frequency distribution showed a significant difference in the two groups ( $p=0.001)$ (Table 2).

There is a negative correlation between vitamin $D_{3}$ levels and $\mathrm{BMI}$ and $\mathrm{HbA} 1 \mathrm{C}$ in patients. Also, a positive correlation was noticed between age and vitamin $D_{3}$ levels, but none of these have significant values in the control group ( $p>0.05$ ) (Table 3).

The results of the comparison of laboratory characteristics of $\mathrm{CHB}$ patients and healthy controls showed that the mean of ALT in patients was $32.82 \mathrm{IU} / \mathrm{mL}$ (8-117) and AST was $32.21 \mathrm{IU} / \mathrm{ML}$ (10-167). Of the all patients in total (21.04\%) had ALT and (17.54\%) had AST higher than $40 \mathrm{IU} / \mathrm{ML}$ while in the healthy group, only $15 \%$ had ALT and $5 \%$ had AST higher than $40 \mathrm{lU} / \mathrm{mL}$. Also, there was a significant difference in ALT and AST between the two groups $(p=0.001)$. Based on this result, between variables such as $L D L$, $\mathrm{HDL}$, and $\mathrm{BMI}$, age, sex, and vitamin $\mathrm{D}_{3}$ levels; was observed no significant difference.

According to the logistic regression results, the risk of vitamin $\mathrm{D}_{3}$ deficiency in men is $45 \%$ higher than in women which is not statistically significant [odds ratio (OR): 1.54, $\mathrm{p}=0.114)$. Among the patients, $75.3 \%$ were urban and $24.7 \%$ were rural residents. The distribution of vitamin $D_{3}$ deficiency in rural people is more than in urban population, which is significant in both groups (OR: 2.321, $\mathrm{p}=0.004)$. There was no significant difference in the BMI distribution between the two groups ( $p=0.13$ ). In general, $47.3 \%$ of patients had a desirable weight, 35.5\% had overweight and $8.2 \%$ had a BMI of more than 30 (Table 4).

\section{Discussion}

This study was conducted for the first time in this province (a region in the East of Iran) regarding vitamin $D_{3}$ pattern in patients with $\mathrm{CHB}$ and also to investigate factors associated with vitamin $\mathrm{D}_{3}$ deficiency in $\mathrm{CHB}$ in comparison with the healthy group. In a period (1990-2010), the prevalence of vitamin $D_{3}$ deficiency was studied in Iranian society, and according to the results, in all regions; both sexes had moderate and significant vitamin $D_{3}$ deficiency (11).

Nghiem et al. showed that vitamin $D_{3}$ deficiency existed in many $\mathrm{CHB}$ patients and this deficiency had a relationship with the complications and outcome of the disease. Decreased liver function due to HBV-induced injuries to liver cells can be one of the causes of vitamin $D_{3}$ deficiency in $\mathrm{CHB}(12,13)$.

The results of this study showed that different degrees of the prevalence of vitamin $D_{3}$ deficiency existed among patients and healthy controls. The duration of exposure to sunlight exposure is an important factor in the changes in vitamin $D_{3}$ levels (14).

\begin{tabular}{|l|l|l|l|}
\hline \multicolumn{2}{|l|}{ Table 1. The baseline characteristics of CHB group by sex } & Female & p-value \\
\hline & Male & $5.43 \pm 1.11$ & 0.343 \\
\hline $\mathrm{HbA1C}(\mathrm{mmol} / \mathrm{mol})$ & $5.71 \pm 1.24$ & $24.7 \pm 2.9$ & 0.595 \\
\hline $\mathrm{BMI}\left(\mathrm{kg} / \mathrm{m}^{2}\right)$ & $25.6 \pm 3.1$ & $29.79 \pm 11.77$ & 0.033 \\
\hline Age $(\mathrm{year})$ & $23.33 \pm 7.76$ & $110.96 \pm 2.0$ & 0.243 \\
\hline $\mathrm{BP}^{1}(\mathrm{mmHg})$ & $120.38 \pm 1.7$ & $76.68 \pm 0.861$ & 0.084 \\
\hline $\mathrm{BP}^{2}(\mathrm{mmHg})$ & $79.91 \pm 1.0$ & $121.44 \pm 123.82$ & 0.131 \\
\hline $\mathrm{FBS}^{3}(\mathrm{mg} / \mathrm{dL})$ & $97.08 \pm 24.5$ & & \\
\hline
\end{tabular}

CHB: Chronic hepatitis B, HbA1C: Hemoglobin A1C, BMI: Body mass index, BP1': Blood pressure (systolic), BP22: Blood pressure (diastolic), FBS3: Fasting blood sugar

Table 2. Distribution frequency of serum vitamin D level in the study groups

\begin{tabular}{|l|l|l|l|l|}
\hline \multicolumn{2}{|l|}{ Group } & $\mathbf{n}$ & Serum vitamin D level & \multicolumn{2}{l|}{} \\
\hline \multicolumn{2}{|l|}{} & Deficiency (n, \%) & Insufficiency (n, \%) & Sufficient (n, \%) \\
\hline Patients & 292 & $184(63.1)$ & $56(19.2)$ & $52(17.8)$ \\
\hline Control & 304 & $100(32.9)$ & $79(26.0)$ & $125(41.15)$ \\
\hline
\end{tabular}

Table 3. Correlation between serum vitamin D levels and assessed variables in the study groups

\begin{tabular}{|c|c|c|c|c|}
\hline \multirow{3}{*}{ Variables } & \multicolumn{4}{|c|}{ Serum vitamin D } \\
\hline & \multicolumn{2}{|l|}{ Case } & \multicolumn{2}{|l|}{ Control } \\
\hline & $r$ & $p$ & $r$ & p \\
\hline BMI $\left(\mathrm{kg} / \mathrm{m}^{2}\right)$ & -0.039 & 0.69 & 0.106 & 0.382 \\
\hline $\mathrm{HbA1C}(\mathrm{mmol} / \mathrm{mol})$ & -0.04 & 0.78 & - & - \\
\hline
\end{tabular}


Table 4. Results of logistic regression for risk of vitamin D deficiency against the variables of interest in the study groups

\begin{tabular}{|c|c|c|c|c|}
\hline \multirow{3}{*}{ Variables } & \multicolumn{2}{|l|}{ Vitamin D } & \multirow{3}{*}{\begin{tabular}{|l} 
Odds ratio \\
$(95 \% \mathrm{CI})$
\end{tabular}} & \multirow{3}{*}{ p-value } \\
\hline & \multicolumn{2}{|l|}{ Deficiency } & & \\
\hline & Yes & No & & \\
\hline Female & $110(37.3 \%)$ & $154(51.9 \%)$ & $*$ & - \\
\hline Urban & $197(70.9 \%)$ & $175(62.1 \%)$ & $*$ & - \\
\hline Mean \pm SD & $24.39 \pm 4.60$ & $25.26 \pm 3.79$ & & - \\
\hline Normal (18.5-24.9) & $47.3 \%$ & $44.4 \%$ & $*$ & - \\
\hline Overweight (25-29.9) & $35.5 \%$ & $40.04 \%$ & $0.72(0.568-1.07)$ & 0.135 \\
\hline Obese $(>30)$ & $8.2 \%$ & $11.1 \%$ & $0.86(0.38-1.93)$ & 0.081 \\
\hline BP1 & $12.28 \pm 1.29$ & $11.42 \pm 1.3$ & $0.39(0.16-1.78)$ & 0.363 \\
\hline $35-44$ & $84(29.3)$ & $91(28.1)$ & $1.21(0.84,1.98)$ & 0.073 \\
\hline $45-54$ & $44(15.5)$ & $72(21.7)$ & 1.079 (0.851-1.367) & 0.341 \\
\hline $55-64$ & $35(12.1)$ & $39(11.6)$ & 1.015 (0.691-1.492) & 0.282 \\
\hline$>65$ & $21(7.1)$ & $18(3.9)$ & * & - \\
\hline $\mathrm{CHB}$ & $184(63.1)$ & 45 (36.9) & 3.17 (1.521-5.913) & - \\
\hline Control & $100(32.9)$ & $204(67.1)$ & $*$ & - \\
\hline
\end{tabular}

In some studies, vitamin $D_{3}$ levels were found to be inversely proportional to HBV-DNA viral load and a sufficient level of vitamin $D_{3}(15)$.

Previous studies showed the association between $D_{3}$ level and $\mathrm{CHB}(16,17,18)$, this study was in line with these studies too (19).

In this study, vitamin $D_{3}$ insufficiency/deficiency accounted for $82.1 \%$ of patients, which was similar to the reported prevalence from Japan and Germany $(20,21)$. However, these results indicate that the relatively high prevalence of vitamin $D_{3}$ deficiency is similar to another study (22). It might be because sunshine hours differ among various latitudes as sunlight-related ultraviolet rays are the substantial factor for vitamin $D_{3}$ synthesis (22). However, this study showed that there was no association between the serum vitamin $\mathrm{D}_{3}$ level and biological factors in both study groups. This failure could be due to variations in the subject's age, HBV genotype, and racial background.

BMI higher than normal is considered to be an effective factor in the level of vitamin $D_{3}$ stores (23). In this study, however, no significant relationship was found between serum levels of vitamin $\mathrm{D}_{3}$ and BMI. This result was different from other studies $(21,22)$.

The current study, showed no association between the biochemical parameters and the serum vitamin $\mathrm{D}_{3}$ level by sex. It is obscurant whether vitamin $\mathrm{D}_{3}$ deficiency is effective in $\mathrm{CHB}$. We assume that sunlight exposure time might be short in the healthy subjects since they might go out less frequently than patients with $\mathrm{CHB}$.

A high prevalence of vitamin $D_{3}$ insufficiency in healthy individuals, as well as $\mathrm{CHB}$ patients, can be associated with consuming poor foods in vitamin $D_{3}$ and lower sun exposure.
Also, the results of Tabrizi et al. (21) as a systematic review study showed a high prevalence of vitamin $D_{3}$ deficiency among the Iranian population. The main reason for the higher vitamin $D_{3}$ deficiency prevalence in these people may be due to spending more time at home, and the clothing that may result in reduced vitamin $D_{3}$ synthesis. Also, the vitamin $D_{3}$ content is low in the Iranian diet (24).

In the published records on the prevalence of vitamin $D_{3}$ deficiency showed that vitamin $D_{3}$ deficiency prevalence was significantly different based on geographical regions in the Iranian population (10). In this study, however, vitamin $D_{3}$ deficiency was not correlated with liver function parameters significantly, probably due to that vitamin $D_{3}$ serum levels are affected by multiple factors. Roughly, one billion people worldwide apparently are vitamin $D_{3}$ deficient $(11,25)$. In line with a previous study (3), our results confirm an inverse correlation between $\mathrm{BMI}$ and $\mathrm{HbA} 1 \mathrm{C}$ loads and vitamin $\mathrm{D}_{3}$ levels in the patients' group.

\section{Study Limitations}

Some limitations of this study were: influencing of several factors on serum vitamin $\mathrm{D}_{3}$ levels; such as seasonal variation, diet, and geographical habitation. However, any information about these affecting factors for study subjects was not available. Another limitation is that vitamin $D_{3}$ may be an additional factor for the clinical outcomes of HBV infection and its interaction with vitamin $D_{3}$ receptor on the pathogenesis of HBV infection needs to be explored further. However, this study could not demonstrate the relevance between assessed variables and serum level vitamin $D_{3^{\prime}}$ partially due to having only a few patients with advanced liver fibrosis. 


\section{Conclusion}

Our study findings reveal that probably this studied population suffers from an insufficiency of vitamin $D_{3}$. This indicates the need to consume foods rich in vitamin $D_{3}$, require higher sun exposure, or vitamin $D_{3}$ supplementation should be recommended in this area. It is noteworthy that although vitamin $D_{3}$ deficiency is apparent in patients, this deficiency is also a noticeable difference with healthy people. Therefore, supplementation of vitamin $D_{3}$ with the initial dose should be recommended and initiated.

\section{Acknowledgment}

We would like to thank all the study subjects for their participation. Dentistry Clinical Research Development Center, Birjand University of Medical Sciences, Birjand, Iran for consulting.

\section{Ethics}

Ethics Committee Approval: This study was approved by the Birjand University of Medical Sciences (BUMS) Ethics Board Committee (approval number: IR.BUMS.REC.1398.324).

Informed Consent: Written consent was obtained from the all of patients.

Peer-review: Externally peer-reviewed.

\section{Authorship Contributions}

Surgical and Medical Practices: FO., M.Z., Concept: F.O., M.Z., Desing: F.O., M.Z., Data Collection or Processing: M.Z., Analysis or Interpretation: FO., M.Z., Literature Search: FO., M.Z., Writing: F.O., M.Z.

Conflict of Interest: No conflict of interest was declared by the authors.

Financial Disclosure: The financial support of the study was provided by the researchers.

\section{References}

1. Arteh J, Narra S, Nair S. Prevalence of vitamin D deficiency in chronic liver disease. Dig Dis Sci 2010;55:2624-2628.

2. Osmani F, Azarkar G. Fitting logistic regression models to assess vitamin D deficiency with clinical parameters in chronic hepatitis $B$ patients. Infectious Disease Modelling. 2021;6:612-617.

3. Coussens AK, Wilkinson RJ, Hanifa Y, Nikolayevskyy V, Elkington PT, Islam K, Timms PM, Venton TR, Bothamley GH, Packe GE, Darmalingam M, Davidson RN, Milburn HJ, Baker LV, Barker RD, Mein CA, Bhaw-Rosun L, Nuamah R, Young DB, Drobniewski FA, Griffiths CJ, Martineau AR. Vitamin D accelerates resolution of inflammatory responses during tuberculosis treatment. Proc Natl Acad Sci U S A 2012;109:15449-15454.

4. Demir C, Demir M. Vitamin D levels in patients with chronic hepatitis B virus infection and naturally immunized individuals. Internal Medicine Inside 2013;1:1-4.

5. Azarkar G, Osmani F. Clinical characteristics and risk factors for mortality in COVID-19 inpatients in Birjand, Iran: a single-center retrospective study. Eur J Med Res 2021;26:79

6. Efe C, Kav T, Aydin C, Cengiz M, Imga NN, Purnak T, Smyk DS, Torgutalp M, Turhan T, Ozenirler S, Ozaslan E, Bogdanos DP. Low serum vitamin $D$ levels are associated with severe histological features and poor response to therapy in patients with autoimmune hepatitis. Dig Dis Sci 2014;59:3035-3042.

7. Fedirko V, Duarte-Salles T, Bamia C, Trichopoulou A, Aleksandrova K, Trichopoulos D, Aleksandrova K, Trichopoulos D, Trepo E, Tjønneland A, Olsen A, Overvad K, Boutron-Ruault MC, Clavel-
Chapelon F, Kvaskoff $M$, Kühn T, Lukanova A, Boeing $H$, Buijsse B, Klinaki E, Tsimakidi C, Naccarati A, Tagliabue G, Panico S, Tumino R, Palli D, Bueno-de-Mesquita HB, Siersema PD, Peters PH, Lund E, Brustad M, Olsen KS, Weiderpass E, Zamora-Ros R, Sánchez MJ, Ardanaz E, Amiano P, Navarro C, Quirós JR, Werner M, Sund M, Lindkvist B, Malm J, Travis RC, Khaw KT, Stepien M, Scalbert A, Romieu I, Lagiou P, Riboli E, Jenab M. Prediagnostic circulating vitamin $\mathrm{D}$ levels and risk of hepatocellular carcinoma in European populations: a nested case-control study. Hepatology 2014;60:1222-1230.

8. Fujii H, Nakai K, Yonekura Y, Kono K, Goto S, Hirata M, Shinohara M, Nishi S, Fukagawa $M$. The vitamin D receptor activator maxacalcitol provides cardioprotective effects in diabetes mellitus. Cardiovasc Drugs Ther 2015;29:499-507.

9. Ghaziasadi A, Ziaee M, Norouzi M, Malekzadeh R, Alavian SM, Saberfar E, Judaki MA, Ghamari S, Khedive A, Namazi A, Rahimnia R, Jazayeri SM. The prevalence of hepatitis $B$ virus surface antigen (HBsAg) variations and correlation with the clinical and serologic pictures in chronic carriers from Khorasan Province, North-East of Iran. Acta Med Iran 2012;50:265-272.

10. Heshmat R, Mohammad K, Majdzadeh S, Forouzanfar M, Bahrami A, Ranjbar Omrani G, Nabipour I, Rajabian R, Hossein-Nezhad A, Rezaei Hemami M, Keshtkar AA, Pajouji M. Vitamin D deficiency in Iran: A multi-center study among different urban areas. Iran J Public Health 2008;37:72-78.

11. Hoan NX, Van Tong H, Le Huu Song CGM, Velavan TP. Vitamin D deficiency and hepatitis viruses-associated liver diseases: A literature review. World J Gastroenterol 2018;24:445-460.

12. Hu YC, Wang WW, Jiang WY, Li CQ, Guo JC, Xun YH. Low vitamin $D$ levels are associated with high viral loads in patients with chronic hepatitis B: A systematic review and meta-analysis. BMC gastroenterol 2019;19:84.

13. Ma Y, Zhang P, Wang F, Yang J, Liu Z, Qin H. Association between vitamin $D$ and risk of colorectal cancer: a systematic review of prospective studies. J Clin Oncol 2011;29:3775-3782.

14. Osmani F, Ziaee M. Assessment of the risk factors for vitamin D3 deŞciency in chronic hepatitis B patient using the decision tree learning algorithm in Birjand. Informatics in Medicine Unlocked. 2021;23:100519.

15. Manco M, Ciampalini P, Nobili V. Low levels of 25-hydroxyvitamin D3 in children with biopsy-proven nonalcoholic fatty liver disease. Hepatology 2010;51:2229-2230

16. Osmani F, Hajizadeh E, Rasekhi A, Akbari ME. Prognostic factors associated with locoronal relapses, metastatic relapses, and death among women with breast cancer. Population-based cohort study. Breast. 2019:48:82-88.

17. Osmani F, Hajizadeh E, Rasekhi A. Association between multiple recurrent events with multivariate modeling: a retrospective cohort study. J Res Health Sci 2018;18:e00433.

18. Plum LA, DeLuca HF. Vitamin $D$, disease and therapeutic opportunities. Nat Rev Drug Discov 2010;9:941-955.

19. Rode A, Fourlanos S, Nicoll A. Oral vitamin D replacement is effective in chronic liver disease. Gastroenterol Clin Biol 2010;34:618-620.

20. Schillie S, Xing J, Murphy T, Hu D. Prevalence of hepatitis B virus infection among persons with diagnosed diabetes mellitus in the United States, 1999-2010. J Viral Hepat 2012;19:674-676.

21. Tabrizi R, Moosazadeh $M$, Akbari M, Dabbaghmanesh $\mathbf{M H}$, Mohamadkhani M, Asemi Z, Heydari ST, Akbari M, Lankarani KB. High prevalence of vitamin D deficiency among Iranian population: a systematic review and meta-analysis. Iran J Med Sci 2018;43:125-139.

22. Wong GL, Chan HL, Chan HY, Tse CH, Chim AM, Lo AO, Wong VW. Adverse effects of vitamin $D$ deficiency on outcomes of patients with chronic hepatitis B. Clin Gastroenterol Hepatol 2015;13:783-790.e1. 
23. Yu R, Sun J, Zheng Z, Chen J, Fan R, Liang X, Zhu Y, Liu Y, Shen $\mathrm{S}$, Hou J. Association between vitamin $\mathrm{D}$ level and viral load or fibrosis stage in chronic hepatitis B patients from Southern China. J Gastroenterol Hepatol 2015;30:566-574.

24. Talaei A, Yadegari N, Rafee M, Rezvanfar M. Vitamin D Deficiency and Its Cut-off Point among young teenagers. Birjand Univ Med Sci 2011;18:210-216.
25. Hoan NX, Khuyen N, Binh MT, Giang DP, Van Tong H, Hoan PQ, Trung NT, Anh DT, Toan NL, Meyer CG, Kremsner PG, Velavan TP, Song LH. Association of vitamin D deficiency with hepatitis $B$ virus-related liver diseases. BMC Infect Dis 2016;16:507. 